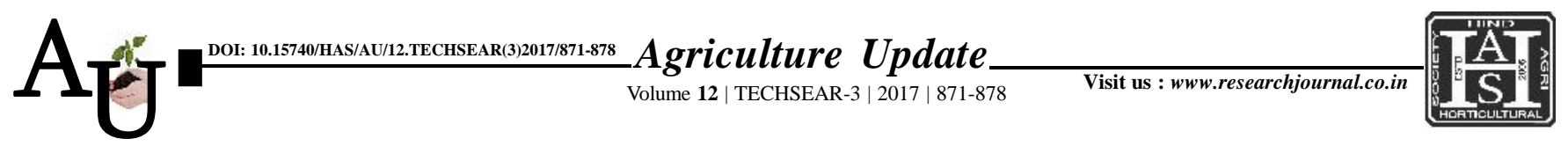

— e ISSN-0976-6847

\title{
A Review : \\ A review on groundnut with organic manures
}

\author{
K. RAMAKRISHNA, K.B. SUNEETHA DEVI AND J.D. SARITHA
}

Article Chronicle: Received :

13.07.2017;

Accepted :

28.07.2017
KEY WoRDS:

Groundnut,

Vermicompost, Mushroom spent substrate
Author for correspondence :

\section{K. RAMAKRISHNA} Department of Agronomy, College of Agriculture, PJTSAU, HYDERABAD (TELANGANA) INDIA Email : ramagronomy@ gmail.com

See end of the article for authors' affiliations
SUMMARY : Groundnut is the principal edible oilseed crop of Andhra Pradesh and Telangana In addition to edible oil, some of the groundnut varieties are recommended as table purpose for human consumption because of its high nutritive value and called as table purpose varieties. Nutrient management in organically grown groundnut is possible through different organic manures without reduction in grain yield. The available literature on the effect of vermicompost, enriched vermicompost, farm yard manure and spent mushroom substrate compost on growth, yield and quality of groundnut was presented underthe relevant heads in the following pages. As the literature in organic groundnut is limited, available literature on integrated nutrient management is also added.

How to cite this article : Ramakrishna, K., Devi, K.B. Suneetha and Saritha, J.D. (2017). A review on groundnut with organic manures. Agric. Update, 12(TECHSEAR-3) : 871-878; DOI: 10.15740/HAS/AU/ 12.TECHSEAR(3)2017/871-878. 